\title{
GENETIC VARIATION WITHIN AND AMONG NATURALLY REGENERATING POPULATIONS OF ALDER (ALNUS GLUTINOSA)
}

\author{
LEON MEJNARTOWICZ \\ Polish Academy of Sciences, Institute of Dendrology \\ Parkowa 5, 62-035 Kórnik, Poland \\ e-mail: lmejnart@man.poznan.pl \\ (Received: July 10, 2007. Accepted: July 23, 2007)
}

\begin{abstract}
To assess the inter- and intrapopulation genetic variation in the filial generation $\left(\mathrm{F}_{1}\right)$ of alder (Alnus glutinosa (L.) Gaertn.), 11 naturally regenerated populations were analysed. Their parental populations (P), represent the whole Polish territory and belong to three phytosociological associations with alder: typical alder swamp forest Carici elongatae-Alnetum (Ce-A); alder riparian forest Circaeo-Alnetum (C-A); and ash-elm riparian forest Fraxino-Ulmetum (F-U).

$F_{1}$ populations are grown in a common-garden experiment (provenance trial). Genotyping of individual trees has been carried out by analysis in a bud tissue allele frequency in the 21 isozyme putative loci of 10 enzymes. Differences between populations in respect to the level of genetic diversity were not high. Genetic diversity measured as the number of effective alleles per locus was the highest $(\mathrm{Ne}=1.65)$ in population Wińsko originating from F-U (where also the inbreeding coefficient was the highest, $\mathrm{F}=0.429)$, and the lowest $(\mathrm{Ne}=1.48)$ in population Sławki from Ce-A. In all investigated populations, observed heterozygosity $(\mathrm{Ho}=20 \%)$ was lower than expected from $\mathrm{H}-\mathrm{W}$ equilibrium $(\mathrm{He}=29 \%)$. The highest genetic variation expressed as percentage of polymorphic loci $(77.3 \%)$ was observed in the offspring populations from Ce-A, and the smallest $(69.9 \%)$ in the populations originating from F-U. It seems that the low genetic differentiation between populations is probably connected with long-distance seed dispersal via river systems. Alder seed can be transported over long distances thanks to periodical flooding. There is some gene flow between alder populations, with about 2.5 immigrants successfully entering a population per generation $(\mathrm{Nm}=2.55)$. The level of population subdivision within A. glutinosa was low $\left(\mathrm{F}_{\mathrm{ST}}=0.089\right)$. There was no significant genetic differentiation between populations from different phytosociological associations. Mantel test exhibited no significant correlation $(r=0.077)$ between genetic and geographic distance. In the dendrogram constructed according to Nei (1972) on the basis of interpopulation genetic distances, many small groups can be observed.
\end{abstract}

KEY WORDS: Alnus glutinosa, climax associations, genetic diversity, genetic distance, gene flow, heterozygosity, rare allele, isozymes.

\section{INTRODUCTION}

Alder, named also European black alder (Alnus glutinosa (L.) Gaertn.), beside grey alder (Alnus incana (L.) Moench.), are ecologically very important European tree species. Alder is wind-pollinated and self-incompatible (McVean 1953). Owing to symbiotic nitrogen-fixing actinobacteria (Frankia alni), both alder species are the only native European forest trees having the ability to fix atmospheric nitrogen and simultaneously act as water and air filters (Peters and Peitzmeier 1989). When growing along river and streams, they protect the river banks from excessive erosion. As a pioneer tree species, alder participates in the first forest stage of plant succession on wet, riparian sites, and can be introduced on dryer, impoverished agrarian and degraded soils (Mejnartowicz 2001). Alder is also a forest-forming species, having an ability to compose climax communities on many soil types in Europe.

On the basis of chloroplast DNA (cpDNA) diversity analyses in alder populations, King and Ferris (1998) tried to describe the postglacial history of this species. These authors revealed a high degree of structuring of some cpDNA haplotypes on a European scale, which indicated that most of northern and central Europe (therefore also the Polish territory), was colonized by alders originating from a refuge in the Carpathian Mountains. This is a well-known fact also for other tree species (Breitenbach-Dorfer et al. 1997; Konnert and Bergmann 1995; Petit et al. 2002)

In European countries, in contrast to many other forest tree species, alder forests are composed of predominantly 
native populations. There are significant differences between alder stands in quantitative and qualitative morphological leaf characters and tree growth dynamics (Mejnartowicz 1972, 1980, 1981, 1999). The genetic differentiation between investigated alder populations is also quite high (Prat et al. 1992). Due to droughts and other climatic changes in the last decade, ground water and surface water levels declined, and this particularly disturbed the ecological relations in the highly structured alder forests (Alnetum). It could be the reason of epidemics of Phytophtora sp. on alders (Cech 1998; Hartmann G. 1995). Therefore, to protect such endangered forests, there is an urgent need to assess the genetic composition of alder populations.

In the early Holocene, around 8000 years ago, the Polish territory was covered with a cool temperate forest and was isolated by the surrounding belt of south taiga forest. As the climate warmed up, south taiga forest withdrew to the north of Europe and the cool temperate forest covered most of Central and West Europe (Adams and Faure 1997). At the end of the early-Holocene isolation, many species started to migrate eastwards and northwards, thus increasing the gene flow from the western European populations of alder and enriching the genetic resources of this species in the area of Poland. This probably applied also to other tree species and can be the reason of the high plasticity of Polish populations of forest tree species observed in international experiments on spruce, pine and fir (Chałupka et al. 2008, Giertych 1978; Gunia and Ilmurzyński 1978; Krutzsch 1992).

The main goal of this study was to answer the following questions:

1) What is the intra- and interpopulation variation of alder populations, studied with isozyme markers?

2) Is there any difference in the genetic structure of populations originating from various natural plant associations when grown in a common-garden experiment?

3) How big is gene flow between alder populations?

4) Is there any connection between the geographic arrangement of populations and their genetic similarity?

\section{MATERIALS AND METHODS}

\section{Plant materials}

Live dormant buds were collected from trees grown in a provenance trial established in 1968, as a kind of common-garden experiment. Parental populations $(\mathrm{P})$ for the trial were selected in such a way that they represented the entire natural range of this species in Poland and thereby located in the centre of the whole European black alder range. Seeds (achenes) from eleven $\mathrm{P}$ populations aged 80-100 years were collected and the filial generation $\left(F_{1}\right)$ has been grown since 1968 in the provenance trial in an Experimental Forest near Kórnik, Poland (Mejnartowicz 1980). The sites of seed material collection for the trial are presented on a map (Fig. 1). Geographic data of the P populations and their geobotanical classification are given in Table 1. The $\mathrm{P}$ populations belong to three main phytosociological associations with Alnus glutinosa of the phytosociological suballiance Alnenion glutinoso-incanae Oberd., (Mejnartowicz 1972; Wojterski 1981), which represent the climax stage of succession. Four of the studied P populations belong to typical alder swamp forest Carici elongatae-Alne-

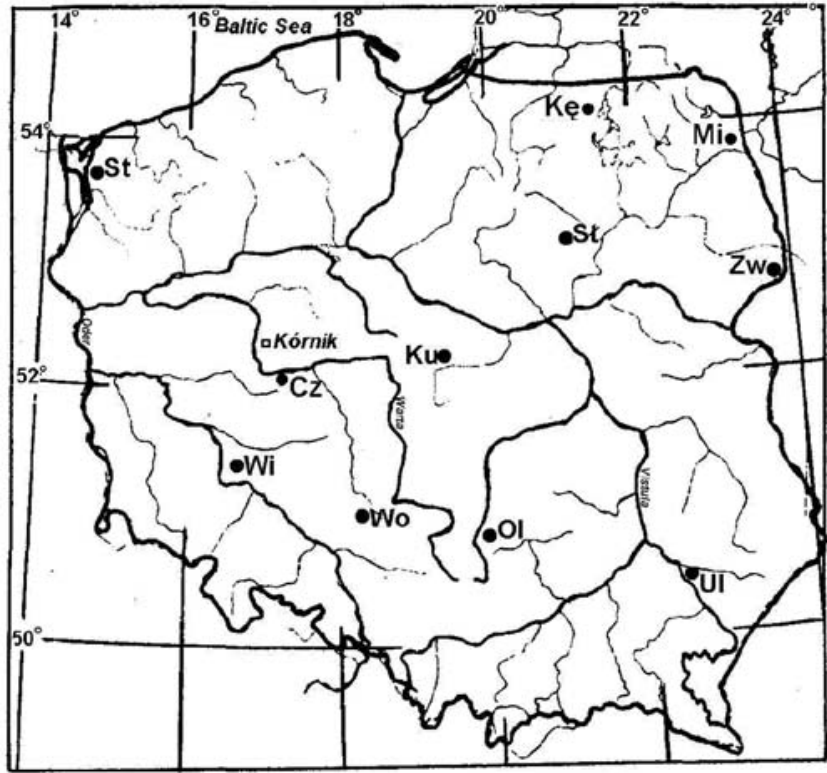

Fig. 1. Location of the studied provenances of Alnus glutinosa.

TABLE 1. Phytosociological and geographical data of investigated populations.

\begin{tabular}{|c|c|c|c|c|}
\hline Population & Association & Latitude & Long & Altitude [m] \\
\hline 1. Czeszewo & $\mathrm{F}-\mathrm{U}^{*}$ & $52^{\circ} 10^{\prime}$ & $17^{\circ} 33^{\prime}$ & 90 \\
\hline 2. Kętrzyn & $\mathrm{Ce}-\mathrm{A}^{*}$ & $54^{\circ} 05^{\prime}$ & $21^{\circ} 30^{\prime}$ & 140 \\
\hline 3. Kutno & C-A* & $52^{\circ} 17^{\prime}$ & $19^{\circ} 08^{\prime}$ & 125 \\
\hline 4. Mikaszówka & $\mathrm{Ce}-\mathrm{A}$ & $53^{\circ} 53^{\prime}$ & $23^{\circ} 20^{\prime}$ & 125 \\
\hline 5. Oleszno & C-A & $50^{\circ} 48^{\prime}$ & $20^{\circ} 05^{\prime}$ & 225 \\
\hline 6. Sławki & $\mathrm{Ce}-\mathrm{A}$ & $53^{\circ} 02^{\prime}$ & $21^{\circ} 06^{\prime}$ & 110 \\
\hline 7. Stepnica & $\mathrm{Ce}-\mathrm{A}$ & $53^{\circ} 36^{\prime}$ & $14^{\circ} 37^{\prime}$ & 2 \\
\hline 8. Ulanów & C-A & $51^{\circ} 32^{\prime}$ & $22^{\circ} 19^{\prime}$ & 200 \\
\hline 9. Wińsko & F-U & $51^{\circ} 26^{\prime}$ & $17^{\circ} 55^{\prime}$ & 150 \\
\hline 10. Wołczyn & F-U & $51^{\circ} 09^{\prime}$ & $18^{\circ} 04^{\prime}$ & 180 \\
\hline 11. Zwierzyniec & C-A & $52^{\circ} 45^{\prime}$ & $23^{\circ} 48^{\prime}$ & 170 \\
\hline
\end{tabular}

F-U* - Fraxino-Ulmetum; Ce-A - Carici elongatae-Alnetum; C-A - Circaeo-Alnetum

tum $(\mathrm{Ce}-\mathrm{A})$, four to alder riparian forest Circaeo-Alnetum (C-A) and three to ash-elm riparian forest Fraxino-Ulmetum (F-U) (Table 1). In Ce-A and C-A, alder is the dominant species, while in $\mathrm{F}-\mathrm{U}$ it is only an admixed tree species.

All $F_{1}$ trees are aged 38 years and they are grown in 4 replications in similar environmental conditions. Such an experimental design diminished the environmental effects on isozyme activity variation in the buds collected for the analysis. Buds were collected on average from 12 nonadjacent trees per population at the end of February. A total of 130 trees were sampled from 11 populations for the intraand interpopulation genetic variance analyses.

\section{Isozyme analysis}

Collected buds were stored at $-70^{\circ} \mathrm{C}$ for up to 1 week (until analysis). In total 21 putative isozyme loci were studied. Leaf primordia from the inner part of the buds were used for electrophoresis on $11.5 \%$ starch gels at $+3^{\circ} \mathrm{C}$. Homogenization was conducted in $150 \mu \mathrm{l}$ of $0.1 \mathrm{M}$ TRIS-HCl, $\mathrm{pH}$ 7.2, buffer containing $10 \mathrm{mg}$ polyclar AT, $30 \mathrm{mg}$ PVP, $15 \mu \mathrm{l} \beta$-mercaptoethanol and $5 \mu \mathrm{l}$ non-ionic surfactant Triton $\mathrm{X}-100$. The electrophoretic procedure was similar to those described in an earlier work on mistletoe (Mejnarto- 
wicz 2006). Visualization of enzymes was based, with small modifications, on the works of Weeden and Wendel (1989).

Ten enzyme systems were assayed: Fluorescence esterase (E.C. 3.1.1.2; FLE), Glutamate-oxaloacetate-transaminase (E.C. 2.6.1.1; GOT), Isocitrate dehydrogenase (E.C. 1.1.1.42; IDH), Malate dehydrogenase (E.C. 1.1.1.37; MDH), Menadione reductase (E.C. 1.6.4.3; MEN), Phosphoglucomutase (E.C. 5.4.2.2; PGM), Phosphoglucose isomerase (E.C. 5.3.1.9; PGI), 6-Phosphogluconic dehydrogenase (E.C. 1.1.1.44; 6PGD), Shikimate dehydrogenase (E.C. 1.1.1.25; ShDH), and Superoxide dismutase (E.C.1.15.1.1; SOD).

As the offspring from controlled crosses of a single tree was not available, the interpretation of zymograms followed previous alder isozyme studies made by Bosquet et al. (1987; 1988), Konnert et al. (2004), Linares-Bensimon (1984), Murillo and Hattemer (1997), and Prat et al. (1992). As a standard reference, well-known isoenzyme zymograms of European silver fir (Abies alba) megagametophytes were used (Bergmann and Mejnartowicz 2002).

Allele frequency was the basis for calculating genetic variation and diversity within populations and genetic distances between populations by using POPGENE software (Yeh and Yang 1999). The statistical Mantel test was used to calculate autocorrelation between matrices of genetic and geographic distances (Mantel 1967).

\section{RESULTS AND DISCUSSION}

In an interesting study of forest communities, Wehenkel et al. (2006) with the help of isoenzyme markers found that pioneer tree species reveal a much higher genetic diversity than the climax tree species. Much earlier, McNaughton and Wolf (1970) discussed a similar question, and concluded that in pioneer species, allelic variation is distributed between individuals while in the climax species allelic variation is distributed within individuals as a high frequency of heterozygous loci. Therefore it was interesting to analyse the genetic structure of populations of alder - the tree species that can be in some circumstances pioneer species but also, as mentioned above, can compose climax communities, i.e. the last stage of plant succession on wetland forest sites.

\section{Genetic variation}

In population biology, genetic variation within demes is usually referred to as diversity. Gillet et al. (2005) considered the effective number of diversity types (e.g. the gene in population) as the heterogeneity of demes, and heterozygosity as genetic variation within individuals. There are several genetic parameters to describe genetic diversity. The most frequently used measures of genetic variation in a population are: 1) proportion of polymorphic loci; and 2) average heterozygosity.

\section{Proportion of polymorphic loci (\%PoL)}

This characteristic was applied for comparing populations from the three phytosociological associations. The analysis of 21 loci of 10 isoenzymes in bud tissues from the 11 populations revealed that $90.5 \%$ loci were polymorphic in all studied individuals. Excluding semipolymorphic loci in the studied populations, $\% \mathrm{PoL}$ amounted to $73.6 \%$. Only both superoxide dismutase loci (SOD1 and SOD2) were homozygous in all populations, while the 6PGD2 locus was semimonomorphic, as it exhibited variation in two alleles in populations Czeszewo and Sławki only (Table 2). In the studied populations, values of $\% \mathrm{PoL}$ ranged between 85.7\% (Sławki, Ce-A) and 61.9\% (Oleszno, C-A, and Mikaszówka, Ce-A). Average value of \%PoL was the highest in $\mathrm{Ce}-\mathrm{A}$ populations $(77.3 \%)$, medium in $\mathrm{C}-\mathrm{A}(72.6 \%)$ and the lowest in F-U $(66.9 \%)$. Those differences between associations (in respect to \% PoL) are not high, thus there seems to be no correlation between the level of genetic polymorphism in a population and the phytosociological association to which this population belongs (Mantel test, $\mathrm{r}=$ 0.077). Hamrick and al. (1992) quote for plants the range of $23-79 \%$ PoL. It means that alder with the value of $74 \%$ is a highly variable tree species, which enables a high level of adaptability to various environmental niches. This result is in good agreement with McNaughton and Wolf's (1970) assumptions that the climax species have individuals with a high frequency of heterozygous loci. The average \% PoL for all studied alder populations is slightly higher than for populations of Norway spruce and European silver fir (PoL $=71 \%$ ) from the Polish territory (Lewandowski and Burczyk 2002; Mejnartowicz 2004).

\section{Heterozygosity}

Other analysed measures of genetic variation included the observed heterozygosity (Ho), i.e. the proportion of individuals that possess at a given locus two different alleles, and expected heterozygosity (He) from Hardy-Weinberg (H-W) equilibrium (Nei 1978). The average He was 0.289 and Ho was 0.200. Differences between populations in $\mathrm{He}$ were smaller than in Ho. Among the three studied associations, the highest average $\mathrm{Ho}=0.211$ and $\mathrm{He}=0.299$ were observed in F-U, and the smallest value $(\mathrm{Ho}=0.183)$ was found in a population originating from C-A (Table 2). Prat et al. (1992) studied Alnus glutinosa in France, by analysing 19 isoenzymatic loci in 37 stands. The mentioned authors reported very similar results for expected heterozygosity $(\mathrm{He}=240)$ to those described above for alder populations from Poland. All studied Polish populations have a positive fixation index $(\mathrm{F}=0.305)$, which indicated a homozygote excess relative to $\mathrm{H}-\mathrm{W}$ equilibrium. A much higher fixation index was calculated by Huh (1999) for Japanese alder (Alnus japonica), where it amounted to $\mathrm{F}=$ 0.502. Alders are capable of generative reproduction, but they also have an ability to regenerate vegetatively by sprouts or root suckers, which increase the chance of mating between relatives. Steiner and Gregorius (1999) observed in black alder natural population comparatively large amounts of self-pollination that not negatively affected seed production. Inbreeding increases the frequency of homozygotes, but it is very probable that the studied alder populations are subdivided, which may have a similar effect to that of inbreeding. Hattemer et al. (2001) suggests that low efficiency of both pollen and seed transport leads to the clumping of genetically similar trees.

\section{Allelic diversity}

Genetic diversity within populations was measured also as mean actual $(\mathrm{Na})$ and effective number $(\mathrm{Ne})$ of alleles per locus, which amounted to 2.62 and 1.59 , respectively. 
TABLE 2. Summary of genetic variation and heterozygosity in the investigated populations of black alder (Alnus glutinosa)

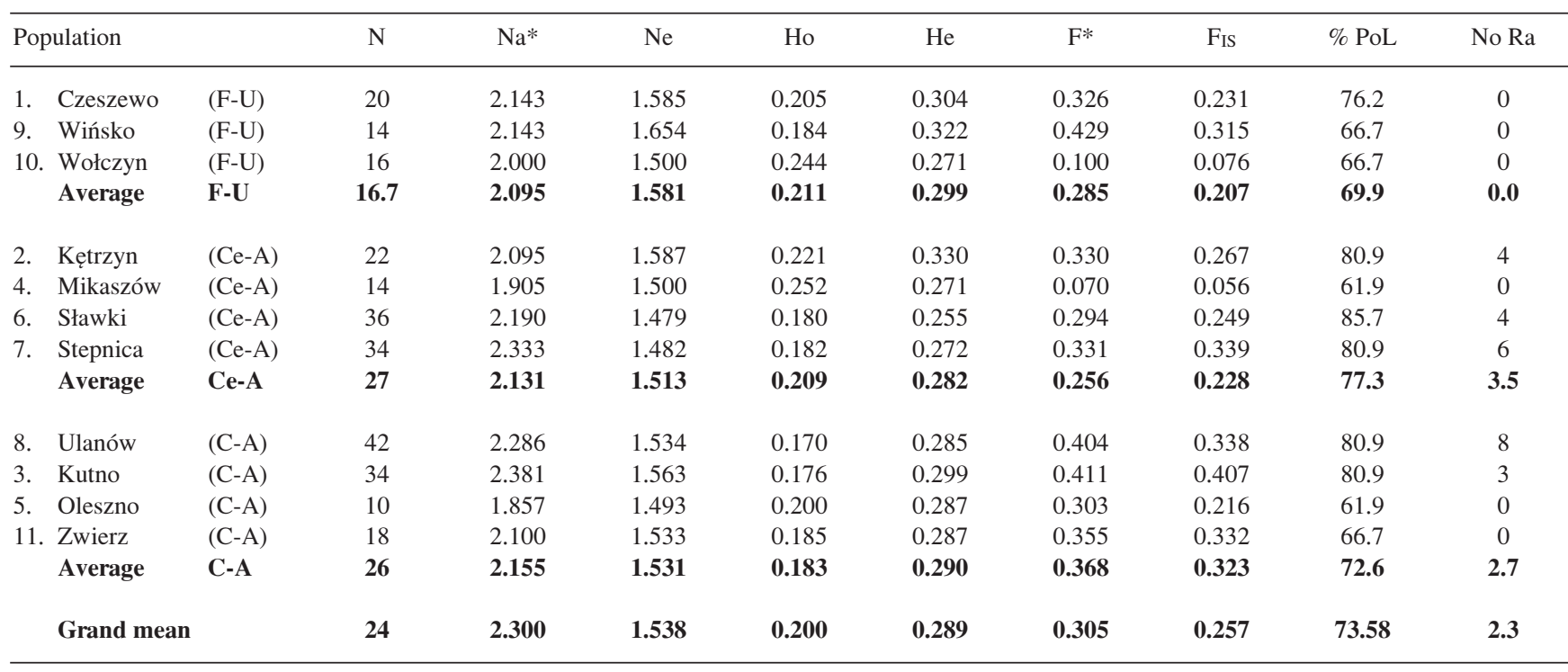

$\mathrm{Na}$ - mean number of observed alleles; $\mathrm{Ne}$ - mean number of effective alleles; Ho - observed heterozygosity; $\mathrm{F}^{*}$ - inbreeding coefficient estimated from: 1-(Ho/He); F and FIS - Wright' fixation indices; \% PoL - percentage of polymorphic loci; NoRa - number of rare alleles

TABLE 3. Wright's (1965) F-statistics and gene flow in investigated populations of alder (Alnus glutinosa).

\begin{tabular}{cccccc}
\hline Species & $\begin{array}{c}\text { Number } \\
\text { of populations }\end{array}$ & F IS & F & F & NT \\
\hline Alnus glutinosa & 11 & 0.271 & 0.336 & 0.089 & 2.554 \\
\hline
\end{tabular}

$* \mathrm{Nm}$ - gene flow estimated from: $\mathrm{Nm}=0.25\left(1-\mathrm{F}_{\mathrm{ST}}\right) / \mathrm{F}_{\mathrm{ST}}$

The smallest $\mathrm{Ne}=1.48$ was in the populations Sławki and Stepnica (Ce-A) in north Poland. Principal component analysis of six polymorphic allozyme loci by Hamann et al. (1998) in Alnus rubra revealed no significant correlations among allozyme frequencies and quantitative traits, but the frequency of the most common allele at most loci decreased with latitude. The average values of $\mathrm{Na}=2.13$ and $\mathrm{Ne}$ $=1.54$ for A. glutinosa populations from Poland are somewhat higher than those calculated by Huh (1999) for Alnus japonica $(\mathrm{Na}=1.93$ and $\mathrm{Ne}=1.39)$. However, both alder species have a similar percentage of polymorphic loci: $74 \%$ for A. glutinosa and $76 \%$ for A. japonica. In the present study, the anemophilous alder has a similar number of effective alleles $(\mathrm{Ne}=1.52)$ to some gymnosperm trees, such as European silver fir $(\mathrm{Ne}=1.55)$, and even higher than that observed for Norway spruce $(\mathrm{Ne}=1.29)$, (Mejnartowicz et al. 2007).

\section{Number of rare alleles (NoRa)}

In respect to the number of rare allele per locus (NoRa) there are big differences between populations. The greatest NoRa $=8$, was found in the Ulanów population $(\mathrm{C}-\mathrm{A})$, but on average the highest $\mathrm{NoRa}=3.5$, was found in the northern populations (Ce-A). Among the eleven studied populations, five had no rare alleles (Table 2).

\section{Genetic differentiation and gene flow}

Genetic differentiation and gene flow between subdivided populations was estimated with conventional Wright's (1965) F-statistics: FIS, FIT, and FST. Gene flow was assessed with indirect method $\left(\mathrm{F}_{\mathrm{ST}}\right)$, using differences between populations in allele frequency: $\mathrm{Nm}=1 /\left(4 \mathrm{~N}_{\mathrm{m}}+1\right)$, where: $\mathrm{N}=$ population size, $\mathrm{m}=$ fraction of $\mathrm{N}$ replaced with immigrants. In the studied populations, $\mathrm{Nm}=2.55$, which means that about 2.5 immigrants reach an average alder population in one generation's duration (Table 3). Slatkin (1987) stated that one migrant per generation is enough to prevent fixation of neutral alleles. Gene flow in the population of wind-pollinated European silver fir is even greater $(\mathrm{Nm}=3.29)$ despite the very heavy pollen of the species (Mejnartowicz 2004). In the dendrogram constructed according to Nei (1972) on the basis of interpopulation genetic distances, many small groups can be observed (Fig. 2). The first one includes only one population: Wińsko (No. 9) from southwestern Poland. The remaining populations form several smaller groups, corresponding neither to phytosociological associations nor to geographic distances. Gene flow among alder populations, mediated by pollen and seeds, can be an evolutionary factor, and is likely to have blurred the existing genetic differentiation between populations from different phytosociological associations. A gene flow was observed, even though infrequently, between A. glutinosa and A. incana, resulting in hybrids trees, which can also affect the genetic structure of the population of both species (Prus-Głowacki and Mejnartowicz 1992).

Woody species like alder - with large geographic ranges, outcrossing breeding systems, and seed dispersal by wind have a higher genetic diversity within species and populations but lower variation among populations than woody species with other combinations of traits (Hamrick 1992). Alder seeds have no wings, so they can be spread by wind only over a distance of 30-60 m around the mother tree. However, alder seeds have air bladders, and thus can be transported over large distances by rivers thanks to periodical flooding. In this way alders can colonize new territories and migrate into other natural alder populations growing on river banks.

The genetic differentiation between populations calculated for 21 investigated loci was low and reached merely the value of $\mathrm{F}_{\mathrm{ST}}=0.089$. This means that $9 \%$ of total genetic variation is due to interpopulation variation, and $91 \%$ is lo- 


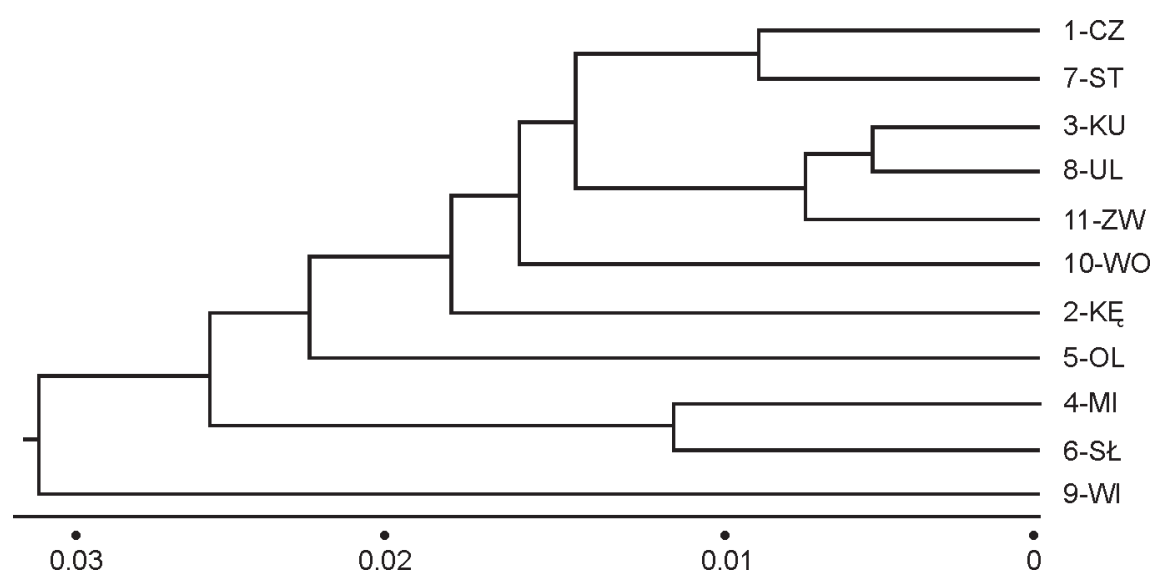

Fig. 2. UPGMA cluster analysis based on Nei's genetic distances among investigated populations of Alnus glutinosa. cated within populations (Table 3). This is much less than in the study of Prat et al. (1992), who found $F_{\text {ST }}=0.204$, but much more than in the study of $A$. glutinosa from central Slovakia investigated by Gömöry and Paule (2002), who found $\mathrm{F}_{\mathrm{ST}}=0.022$. The population differentiation of A. glutinosa in Poland is similar to that of A. rugosa in Canada $\left(\mathrm{F}_{\mathrm{ST}}=0.052\right)$ and $A$. japonica in Korea $\left(\mathrm{F}_{\mathrm{ST}}=0.095\right)$, (Huh 1999).

The vast majority of investigated loci have intermediate FST values, indicating a neutral character of allelic variation in these loci. On the scale of Poland, no clear genetic pattern of similarity between populations was recorded, perhaps due to gene flow between populations, more by seeds than by the pollen. Differentiation within regional groups $\left(F_{I S}=0.271\right)$ suggested that mating was mainly random in the populations (Table 3 ).

\section{CONCLUSIONS}

Alder populations are found usually in the vicinity of watercourses. Alder seeds are not spread far away by wind, but can be spread by running water over large distances. This study revealed no significant correlation between genetic and geographic distance between populations, and between genetic distance and phytosociological classification. It seems that the spatial genetic structure of alder populations was formed in connection to the hydrological system of the country.

The value of $\mathrm{F}_{\mathrm{ST}}=0.089$ indicates small differences between populations. Only $8.9 \%$ of the total variation is due to interpopulation differences. Most of the analysed loci

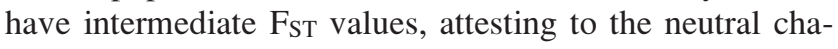
racter of allelic variation at these loci. Gene flow estimates $(\mathrm{Nm}=2.55)$ showed that reproductive barriers do not separate populations of A. glutinosa.

In 10 studied isozyme systems in 21 putative loci, with altogether 56 alleles, a high level of genetic variation within populations was revealed by the mean number of actual alleles $(\mathrm{Na}=2.3)$ and of effective alleles $(\mathrm{Ne}=1.54)$ per locus. Expected heterozygosity (He) amounted to $28.9 \%$, while observed heterozygosity (Ho) reached $20.0 \%$. All studied Polish populations have a positive fixation index $(F=0.305)$, which indicated a $30 \%$ deficiency of heterozygotes. This could be explained by the fact that alder regenerates generatively but also has an ability to regenerate vegetatively by sprouts or root suckers, and this increases the chance of mating between relatives.

\section{ACKNOWLEDGEMENT}

This work was financially supported by the Institute of Dendrology PAS, Kórnik, Poland.

The author is grateful to J. Kozłowska for her excellent technical assistance and to P. Kosiński for his statistical advices.

\section{LITERATURE CITED}

ADAMS J.M., FAURE H. 1997. Review and Atlas of Palaeovegetation: Preliminary land ecosystem maps of the world since the Last Glacial Maximum. Oak Ridge National Laboratory, TN., USA.

BERGMANN F. MEJNARTOWICZ L. 2002. Substrate specificity of glucokinase and fructokinase of several conifer species. Acta Soc. Bot. Pol. 71 (2): 125-127.

BOUSQUET J., CHELIAK W.M., LALONDE M. 1987. Allozyme variability in natural populations of green alder (Alnus crispa) in Quebec. Genome 29: 345-352.

BOUSQUET J., CHELIAK W.M., LALONDE M. 1988. Allozyme variation within and among mature populations of speckled alder (Alnus rugosa) and relationships with green alder (A. crispa). Am. J. Bot. 75: 1678-1686.

BREITENBACH-DORFER M., KONNERT M., PINSKER W., STARLINGER F., GEBUREK T. 1997. The contact zone between two migration routes of silver-fir, Abies alba (Pinaceae), revealed by allozyme studies. Pl. Syst. Evol. 206 (1-4): 259-272.

CECH T.H. 1998. Phytophthora decline of alder (Alnus spp.). Eur. J. Arboricult. 24 (6): 297-300.

CHAŁUPKA W., MEJNARTOWICZ L., LEWANDOWSKA A. 2008. Reconstitution of a lost forest tree population: A case study of Norway spruce (Picea abies [L.] Kaest.). For. Ecol. Manage. 255: 2103-2108.

GIERTYCH M. 1978. Plastyczność polskich ras świerka (Picea abies (L.) Karst.) w świetle międzynarodowego doświadczenia IUFRO z lat 1964-1968. Arboretum Kórnickie 23: 187-206. (in Polish)

GILLET E., GÖMÖRY D., PAULE L. 2005. Measuring genetic variation within and among populations at marker loci. In: T. Geburek, J. Turok (eds). Conservation and Management of Forest Genetic Resources in Europe. Arbora Publ. Zvolen: 237-273.

GÖMÖRY D., PAULE L. 2002. Spatial and microgeographical genetic differentiation of black alder (Alnus glutinosa Gaertn.) populations. Forest Ecol. Manag. 160 (1-3): 3-9.

GUNIA S., ILMURZYŃSKI E. 1978. Wybrane zagadnienia hodowli selekcyjnej drzew leśnych. SGGW AR Wydział Leśny, Warszawa: 70-74.

HAMANN A., El-KASSABY Y.A., KOSHY M.P., NAMKOONG G. 1998. Multivariate analysis of allozymic and quanti- 
tative trait variation in Alnus rubra: geographic patterns and evolutionary implications. Can. J. For. Res. 28 (10): 1557$-1565$.

HAMRICK J.L., GODT M.J.W., SHERMAN-BROYLES S.L. 1992. Factors influencing levels of genetic diversity in woody plant species. N. Forests 6: 95-124.

HARTMANN G. 1995. Wurzelhalsfäule der Schwarzerle (Alnus glutinosa) - eine bisher unbekannte Pilzkrankheit durch Phytophthora cambivora. Forst und Holz 50 (18): 555-557.

HATTEMER H.H., ZIEHE M., FINKELDEY R., FROMM M. 2001. Genetic diversity and differentiation of individual effective pollen clouds in trees. In: Müller-Starck G., Schubert R. (eds). Genetic Response of Forest Systems to Changing Environmental Conditions. Vol. 70: 223-237. Kluwer Acad. Publ., Dordrecht-Boston-London.

HUH M.K. 1999. Genetic diversity and population structure of Korean alder (Alnus japonica; Betulaceae). Can. J. For. Res. 29 (9): 1311-1316.

HUNTLEY B. 1990. Dissimilarity mapping between fossil and contemporary pollen spectra in Europe for the past 13,000 years. Quaternary Research 33: 360-376.

KING A.R., FERRIS C. 1998. Chloroplast DNA phylogeography of Alnus glutinosa (L.) Gaertn. Molecular Ecol. 7: 1151-1162.

KONNERT M., BERGMANN F. 1995. The geographical distribution of genetic variation of Silver fir (Abies alba, Pinaceae) in relation to its migration history. P1. Syst. Evol. 196: 19-30.

KONNERT M., WIMMER T., NOWAK S., HÄUSL E., MADER K. 2004. Isoenzymuntersuchungen bei Schwarzerle ( $A l$ nus glutinosa). Bund-Länder-Arbeitsgruppe "Erhaltung forstlicher Genressourcen". ASP Teisendorf.: 1-17.

KRUTZSCH P. 1992. IUFRO's role of coniferous tree improvement: Norway spruce (Picea abies (L.) Karst.) Silvae Genetica. 41 (3): 143-150.

LEWANDOWSKI A., BURCZYK J. 2002. Allozyme variation of Picea abies in Poland. Scand. J. For. Res. 17 (6) 487-494.

LINARES-BENSIMON C. 1984. Versuche zur Viabilitätsselection an Enzym-Genloci bei Alnus glutinosa (L.) Gaertn. Göttingen Res. Not. Forest Gen. 7: 1-137.

MANTEL N. 1967. The detection of disease clustering and a generalized regression approach. Cancer Res. 27: 209-220.

McNAUGHTON S.J., WOLF L.L. 1970. Dominance and the niche in ecological systems. Science 167: 131-139.

McVEAN D.N. 1953. Biological flora of the British Isles: Alnus glutinosa (L.) Gaertn. J. Ecol. 41: 447-466.

MEJNARTOWICZ L. 1972. Studies on the variability of Alnus glutinosa (L.) Gertn. populations in Poland. Arboretum Kórnickie 17: 43-120. (in Polish).

MEJNARTOWICZ L. 1980. Studies on racial variation of black alder in Poland. Arboretum Kórnickie 25: 167-180. (in Polish)

MEJNARTOWICZ L. 1981. Genetyka. Monografia: Olsze - Alnus Mill. "Nasze Drzewa Leśne". Ed. S. Białobok, PWN Poznań 8: 201-228. (in Polish)

MEJNARTOWICZ L. 1982. Morphology and growth of Alnus incana $x$ glutinosa $\mathrm{F}_{1}$ hybrid. Arboretum Kórnickie 26: 15-29.

MEJNARTOWICZ L. 1999. Evidence for long term heterosis phenomenon in the Alnus incana $\times$ glutinosa $\mathrm{F}_{1}$ hybrids. Silvae Genet. 48: 100-103.

MEJNARTOWICZ L. 2001. Biological response of alder trees to environmental pollution. In: Müller-Starck G., Schubert R. (eds). Genetic Response of Forest Systems to Changing Envi- ronmental Conditions. Vol. 70: 63-73. Kluwer Acad. Publ., Dordrecht-Boston-London.

MEJNARTOWICZ L. 2004. Genetic Analysis of Silver-fir populations in the North Carpathian and Sudeten Mountains. Acta Soc. Bot. Pol. 73 (4): 285-292.

MEJNARTOWICZ L. 2006 Relationship and genetic diversity of Viscum album subspecies. Acta Soc. Bot. Pol. 75 (1): 39-44.

MEJNARTOWICZ L., CHAŁUPKA W., LEWANDOWSKI A. 2007. Isozyme marker genes as a tool for identification of a lost population. IUFRO Congress Tree Biotechnology 2007, Ponota Delgada, Portugal 3-8 June 2007, Section IV. Pop. Gene. Conserv. S. IV. 6.

MURILLO O., HATTEMER H.H. 1997. Inheritance of isozyme variants of Alnus acuminata ssp. arguta (Schlectendal) Furlow. Silvae Gen. 46 (1): 51-55

NEI M. 1972. Genetic distance between populations. Amer. Natur. 106: 283-292.

NEI M. 1978. Estimation of average heterozygosity and genetic distance from a small numbers of individuals. Genetics 89: 583-590.

PETERS U., PEITZMEIER E. 1989. Vergleichende Untersuchungen der Schwermetallgehallte eines Erlen-Eschen-Bruchwaldes im Ruhrgebiet (Bochum) und am Rand der Südeifel. - Verh. Ges. Ökol. 18: 131-138.

PETIT R.J., BREWERS S., BORDACS S., BURG K., CHEDDADI R., COART E., COTTRELL J., CSAIKL U.M., VAN DAM B., DEABS J.D., ESPINEL S., FINESCHI S., FINKELDEY R., GLAZ I., GOICOECHEA P.G., JENSEN J.S., KONIG A.O., LOWE A.J., MADESN S.F., MATYAS G., MUNRO R.C., POPESCU F., SLADE D., TABBENER H., DE VRIES S.G.M., ZIEGENHAGEN B., DE BEAULIEU L., KREMER A. 2002. Identification of refugia and postglacial colonization routes of European white oaks based on chloroplast DNA and fossil pollen evidence. For. Ecol. Manage.156 (103): 49-74.

PRAT D., LEGER C., BOJOVIC S. 1992. Genetic diversity among Alnus glutinosa (L.) Gaertn. populations. Acta Oecolog. 13 (4): 469-477.

PRUS-GŁOWACKI W., MEJNARTOWICZ L. 1992. Serological Investigation of Alnus incana $\times$ glutinosa hybrids and their parental species. Silvae Gen. 41 (2): 65-70.

SLATKIN M. 1987. Gene flow and the geographical structure of natural populations. Science 236: 787-792.

STEINER W., GREGORIUS H.R. 1999. Incompatibility and pollen competition in Alnus glutinosa: Evidence from pollination experiments. Genetica 105 (3): 259-271.

WENDEL J.F., WEEDEN N.F. 1989. Visualization and interpretation of plant isozymes. In: D.E. Soltis, P.S. Soltis (eds). Isozymes in Plant Biology. Chapman \& Hall. London: 5-45.

WEHENKEL C., BERGMANN F., GREGORIUS H.R. 2006. "Is there a trade-off between species diversity and genetic diversity in forest tree communities? Plant Ecol. 185 (1): 151-161.

WOJTERSKI T. 1981. Lasy olszowe. In: Olsze - Alnus Mill. "Nasze Drzewa Leśne". Ed.: S. Białobok. PWN Poznań, T. 8: 260-279. (in Polish)

WRIGHT S. 1965. The interpretation of population structure by F-statistics with special regard to system of mating. Evolution 19: 395-420.

YEH F.C., YANG R. 1999. Popgene version 1.31. Freeware for population genetic analysis. 